\title{
DO REFLEKSJI
}

DOI: $10.5604 / 01.3001 .0013 .7259$

\section{MirosŁaw Górecki}

ORCID https://orcid.org/0000-0002-8988-5006

\section{STARZENIE SIĘ I STAROŚĆ W ASPEKCIE POLITYKI SPOŁECZNEJ}

\section{ABSTRAKT}

W ostatnim czasie wśród pedagogów społecznych wzrosło zainteresowanie procesem starzenia się społeczeństwa polskiego i zjawiskiem starości, choć rzadko wcześniej były one podejmowane w badaniach i publikacjach z zakresu tej dyscypliny. W artykule przedstawiono wybrane aspekty i konsekwencje tej problematyki oraz związane z nią wyzwania społeczne. Szczególnie skoncentrowano się na starzeniu się jako globalnym procesie demograficznym, postawach społecznych wobec ludzi starych i starości, różnych modelach opieki nad osobami starymi w państwach Unii Europejskiej, aktywności edukacyjnej i społecznej seniorów. Na zakończenie sformułowano najważniejsze zadania, które wynikają dla polityki społecznej i organizacji opieki geriatrycznej.

Słowa kluczowe: starzenie się, starość, postawy, przygotowanie do starości, polityka społeczna

\section{WPROWADZENIE}

D roblematyka starzenia się i starości zajmuje w pedagogice społecz1 nej i pracy socjalnej bardzo ważne miejsce. Już Helena Radlińska w 1938 r. (s. 88) pisała o społeczno-kulturowym i edukacyjnym znaczeniu starości oraz ludziach starych, „którzy wyzwoliwszy się z trudów przymusowych i z namiętności, dążą ku poznaniu tajemnic wiekuistych”. Natomiast w latach 70. ubiegłego wieku koncepcję wychowania do starości zarysował Aleksander Kamiński. Wymienił elementy tego wychowania, a mianowicie rozwój zainteresowań, aktywność społeczną i polityczną, naukę zawodu rezerwowego, nauczenie się higieny życia, rozszerzenie swych nawyków kulturalnych. Sądził, że przygotowania do tego okresu należy rozpocząć wcześnie. Właściwie jest nim całe dorosłe życie (Kamiński, 1978, s. 359, 
375). Późniejsze opracowania z tego zakresu mieszczą się w tak zakreślonych ramach problemowych.

Starość to ostatni etap w życiu człowieka, rozpoczynający się wraz z osiągnięciem określonego umownie „progu starości”. Ustalenie w sposób precyzyjny granicy, od której mamy do czynienia z człowiekiem starym nie do końca jest możliwe ze względu na indywidualne cechy osób objętych generalnie tym przedziałem wieku. Wprawdzie pojawiające się zmiany charakteryzują się podobnym kierunkiem, to jednak różnią się znacznie natężeniem, tempem czy długością zachodzących procesów (Harwas-Napierała, Trempała, 2003, s. 264-265). Na ogół za próg starości uznaje się 65. rok życia. Stosuje się również kryterium wieku emerytalnego. Jednakże jest to kwestia całkowicie umowna, bo wiek emerytalny dla różnych grup zawodowych nawet w przybliżeniu nie pokrywa się z rzeczywistą starością. Ze względu na wydłużającą się średnią długość życia i poprawę jego jakości należy spodziewać się $\mathrm{w}$ przyszłości podwyższenia progu starości, na co wskazuje choćby coraz częstsze podnoszenie w wielu państwach dolnej granicy wieku emerytalnego. Rozstrzygnięcia te są podyktowane zarówno względami ekonomicznymi, jak i dobrą kondycją psychosomatyczną osób formalnie kwalifikujących się do uzyskania statusu emeryta, które jednak czują się zdolne do dalszego świadczenia pracy.

\section{StARZENIE SIĘ JAKO GLOBALNY PROCES DEMOGRAFICZNY}

Do najważniejszych problemów w krajach wysoko rozwiniętych należy starzenie się społeczeństw. Według danych Organizacji Narodów Zjednoczonych na całym świecie w 2013 r. w wieku 65 lat i więcej było 570459000 osób, w tym 316742000 kobiet i 253722000 mężczyzn, zaś w wieku 80 lat i więcej - 120199000 osób, w tym 74178000 kobiet i 46024000 mężczyzn (World Population Ageing, 2013, s. 90), najwięcej w Chinach (23 mln), Stanach Zjednoczonych (12 mln), Indiach $(10 \mathrm{mln})$ i Japonii (9 mln) (tamże, s. 32). Znacznie przybyło też osób w wieku 100 lat i więcej. W tej grupie wiekowej było 441000 , a według prognoz do 2050 r. liczba ta wzrośnie prawie ośmiokrotnie (do 3400 000) (tamże, s. 32). W 2018 r. w Polsce w wieku 65 lat i więcej było 6732360 osób (17,5\%), w tym 
4063276 kobiet i 2669084 mężczyzn (Rocznik Demograficzny, 2019, s. 143). Mamy więc do czynienia z feminizacją starości. Jest to tendencja ogólnoświatowa wynikająca z faktu zdeterminowanego biologicznie dłuższego życia kobiet.

W Polsce wzrost odsetka osób starych w wieku 65 lat i więcej był systematyczny: 5\% w 1950 r., 10\% w 1980 r., 13,4\% w 2010 r. (Okólski, 2018, s. 117; Rocznik Demograficzny, 2019, s. 137, 138). Po 2010 r. wzrost odsetka seniorów wyraźnie przyspieszył i jak wynika z opracowanych prognoz przez GUS, ONZ czy Eurostat w najbliższych latach będzie się gwałtownie zwiększał. Według prognozy Mig/Ageing ${ }^{1)}$ w okresie 2015-2060 odsetek ludzi starych w wieku 65 lat i więcej wzrośnie z 15,8\% do 31,4\%, a w wieku 80 lat i więcej z 3,95 do 11,2\%. Proces starzenia będzie narastać szczególnie szybko w latach 2015-2025 i 2040-2050 (Okólski, 2018, s. 401). W 2018 r. przeciętne dalsze trwanie życia dla kobiet wynosiło 81,8 lat, a dla mężczyzn 73,9 lat (Rocznika Demograficznego, 2019, s. 502). W państwach wysoko rozwiniętych wskaźnik ten z roku na rok wyrównuje się, co wynika z większej dynamiki wydłużania się życia wśród mężczyzn niż wśród kobiet.

Głównymi przyczynami starzenia się społeczeństw są wydłużanie się życia ludzkiego i malejąca liczba urodzeń. Do najbardziej istotnych czynników wpływających na zwiększanie się długości życia zalicza się postępy w medycynie, rozwój usług opiekuńczych, modę na zdrowy tryb życia, podniesienie poziomu życia i kultury zdrowotnej, propagowanie badań profilaktycznych, wyeliminowanie wielu chorób do niedawna dziesiątkujących ludzkość. Natomiast przyczynami malejącej liczby urodzeń są: świadome opóźnianie zawierania małżeństw i prokreacji, trudności na rynku pracy i dyskryminacja płacowa kobiet, wysokie koszty utrzymania dziecka zniechęcające młodych ludzi do zakładania rodziny, emigracja młodych ludzi w poszukiwaniu lepszych warunków życia i pracy, przemiany w strukturze i formach rodzin (nie kultywuje się już modelu rodziny wielodzietnej, bo ważniejsze jest np. osiągnięcie

1) Mig/Ageing to projekt pod nazwą „Niezakończone przejście migracyjne a starzenie się ludności w Polsce. Asynchroniczność przemian ludnościowych a zmiana formalnych i nieformalnych instytucji opiekuńczych”, który był realizowany przez cztery lata, poczynając od 1 października 2013 r. przez interdyscyplinarny zespół Ośrodka Badań nad Migracjami Uniwersytetu Warszawskiego. 
sukcesu przez rodziców i przez dziecko), upowszechnianie się alternatywnych modeli rodziny (Kwak, 2005, s. 70-96; Szlendak, 2000, s. 317-320) i strategii życiowych „nierodzinnych” (single/singielki) (Izdebski, Paprzycka, 2016), zwiększanie się aktywizacji zawodowej kobiet, wzrost aspiracji zawodowych i pozazawodowych kobiet, dominacja konsumpcyjnego stylu życia, gwarancje opieki publicznej w ciągu całego życia. Od kilku lat mamy w Polsce ujemny przyrost naturalny: $-25,6 \%$ w 2015 r., $-5,8 \%$ w 2016 r., $-0,9 \%$ w 2017 r., -26,0\% w 2018 r. (Rocznik Demograficzny, 2019, s. 80). W 2017 r. współczynnik dzietności wyniósł 1,48, co nie gwarantuje zastępowalności pokoleń (dopiero liczba 2,10-2,15 zapewnia tę zastępowalność), a średni wiek Polek rodzących dzieci to 29,5 lat (tamże, s. 482).

Przytoczone dane liczbowe obrazują doniosłość problemu starości i związanych z nią zadań w wielu dziedzinach życia społecznego, które wymagają zarówno zintensyfikowania badań naukowych, jak i poszukiwania rozwiązań praktycznych.

\section{STOSUNEK SPOłECZEŃSTW DO LUDZI STARYCH I DO STAROŚCI}

Postawy wobec osób starych są oczywiście uwarunkowane kulturowo, czego dowodzą badania antropologiczne, etnologiczne i historyczne (Janiak-Jasińska, Sierakowska, Szwarc, 2016). We współczesnych cywilizacjach stosunek do starości zależy głównie od ogólnie przyjętej hierarchii wartości. Tam, gdzie do wartości naczelnych zalicza się mądrość życiową ${ }^{2)}$, starość jest ceniona i szanowana ${ }^{3)}$. Tam zaś, gdzie wartościami naczelnymi stają się młodość, kult ciała i pomnażanie dóbr materialnych osoby stare straciły

2) To pojęcie obejmuje poznanie siebie i innych, znajomość prawidłowości rządzące życiem psychospołecznym, umiejętne i skuteczne urzeczywistnienie celów i zadań życiowych, realizowanie akceptowanej przez siebie hierarchii wartości i życia zgodnego z nimi, samorealizację i rozwój własnych uzdolnień, wykorzystywanie swoich mocnych stron i zalet. Nie chodzi więc tu o mądrość w sensie intelektualnym, ale o ten jej wymiar, który określa się mądrością życiową, opartą raczej na podstawie doświadczeń i roztropności niż wiedzy.

3) Pozytywny stosunek do starości i osób starych był również w kulturze starożytnej Grecji i Rzymu. 
swą wysoką pozycję i znalazły się w jednej z najsłabszych grup społecznych. Do dyskryminacji ludzi starych dochodzi szczególnie w społeczeństwach zachodnich, mających obsesję młodości.

W społeczeństwach tradycyjnych starość była ceniona przez fakt, że istotne znaczenie dla trwania młodych pokoleń miała mądrość życiowa pokoleń odchodzących. Tę gromadzoną przez całe życie mądrość zastąpiła dziś wiedza, której kształt zmienia się nieomal z dnia na dzień. I paradoksalnie obecnie to ludzie starzy uczą się od młodych: technik informacyjnych, obsługi kart bankomatowych itd.

Współcześnie wyróżnia się dwa oblicza starości. Z jednej strony docenia się jej zalety i wartości, a z drugiej - widzi się w niej okres całkowitej degradacji, izolacji, samotności, niedołęstwa, postępującego uzależnienia od otoczenia, utraty osób bliskich, lęku przed umieraniem. Osoby stare często są traktowane jako „obywatele drugiej kategorii, nie mający nic do zaoferowania innym" (Nelson, 2005, s. 209) i w sposób przedmiotowy, bo wyręcza się je we wszystkim, nawet nie dopuszcza do podejmowania wyborów związanych z własnym życiem. W tym tkwi jedno ze źródeł wyuczonych postaw roszczeniowych.

Osoby młode i w średnim wieku w kontaktach z ludźmi starymi często kierują się uprzedzeniami, które prowadzą nawet do dyskryminacji. Zjawisko to określa się jako ageizm (Marshall, 2004, s. 421) ${ }^{4}$. Zdaniem amerykańskiego gerontologa Roberta Neila Butlera (1969, s. 243-246; 1975, s. 48) ageizm to proces systematycznego tworzenia przekonań, uprzedzeń i stereotypów oraz dyskryminowania ludzi starych z powodu ich wieku. Może on przyjmować różne formy - od lekceważenia, ośmieszania, zastraszania, poniżania, zaniedbywania (np. odmowa podawania posiłków, porzucenie w szpitalu czy w domu pomocy społecznej), po izolację społeczną, marginalizację, nadużycia finansowe i prawne, aż do działań eutanatycznych.

Przy niemal powszechnym uznaniu, że społeczeństwo ma obowiązki wobec ludzi starych, mamy do czynienia ze stereotypami (np. niedołężność, bezradność, osamotnienie, nieatrakcyjność, nieużyteczność, aseksu-

4) W języku polskim jego odpowiednikiem jest pojęcie „wiekizm” przez analogię do takich określeń jak „rasizm” czy „seksizm”. 
alność). Powszechne jest również przekonanie, że ludzie starzy są zbyt kostyczni, mało elastyczni i nie chcą lub nie potrafią uczyć się nowych rzeczy (Leiblum, Segraves, 2005, s. 492), a przecież nawet seniorzy są zdolni do przeprowadzania zmian i innowacji (Storr, 2010, s. 61).

Przeciwdziałanie stereotypom, uprzedzeniom, dyskryminacji osób starych nie tylko wpływa na poprawę ich sytuacji w społeczeństwie, lecz także sprzyja racjonalnemu gospodarowaniu ich potencjałem. Wszak seniorzy to osoby o znacznym kapitale ludzkim (wiedza i doświadczenie) i społecznym (sieć więzi społecznych). Konieczne jest uświadomienie, zwłaszcza młodemu pokoleniu, że starość jest fazą życia, której dożywa większość ludzi i ten okres może być również twórczy i interesujący, w którym seniorzy mogą spożytkować swoją energię życiową na rzecz działań międzypokoleniowych i wspólnoty lokalnej. Pozytywnych przykładów przeczących stereotypowi schorowanego, nieużytecznego i biernego seniora jest wiele, od aktywności edukacyjnej w uniwersytetach trzeciego wieku, poprzez działania na rzecz rodzinnej integracji trzech pokoleń, do działalności wolontariackiej.

Skrajną formą ageizmu jest gerontofobia określana jako „irracjonalna obawa przed ludźmi starymi, przed kontaktem z nimi, jak i przed procesem starzenia się rozumianym jako proces przemijania" (Szukalski, 2008, s. 158-159); wrogi stosunek do osób starych, przy równoczesnym obniżeniu ich statusu społecznego, traktowanie ich jako ciężaru społecznego. Znajduje to wyraz także w języku. Człowieka starego nazywa się: „ramol”, „próchno”, „resor”, „bujak”, „pryk”, „parkinson”, „antyk”, „stara pudernica”, „resetka”, „wygaszacz”, ,z tyłu liceum, z przodu muzeum”, „darmowy monitoring" (w Stanach Zjednoczonych natomiast używa się określenia „szlafrokowa policja” - i nie ma ono zabarwienia pejoratywnego), zaś o wieczorze spędzonym w towarzystwie ludzi starych mówi się: „wieczór w tonacji ra-moll” (Kaczmarek, Skubalanka, Grabias, 1994, s. 39; Potent-Ambroziewicz, 2013, s. 57-190). Przeciwieństwem tak negatywnych określeń są eufemizmy: ,jesień życia”, „trzeci wiek”, „czwarty wiek”, „zaawansowany wiek”, „nie pierwszej młodości”, „w pewnym wieku”, „starszawy”, „niemłody”, a najczęściej - „osoby starsze”.

Z przeprowadzonych badań przez Małgorzatę Potent-Ambroziewicz na populacji uczniów szkół średnich wynika, że 30\% respondentów przyznało 
się do świadomego unikania kontaktów z osobami starymi, a jako przyczyny takiego zachowania wymienili: brak cierpliwości, lęk przed krytyką, niechęć, obrzydzenie, współczucie, bezsilność, bezradność. Z kolei 17\% badanych świadomie tego kontaktu szuka i z tego powodu podejmuje pracę wolontariacką na rzecz seniorów, odnosząc następujące korzyści: spokój i wyciszenie, dystans do rzeczywistości, „dobre rady” i poczucie humoru (Potent-Ambroziewicz, 2013, s. 21-22).

Każdy młody człowiek powinien przez pewien czas pracować z ludźmi starymi, bo wzbudzają podziw w zmaganiu się z problemami życia codziennego, ale również dlatego, żeby zobaczyć, co czeka ewentualnie każdego $\mathrm{z}$ nas. Jednakże studenci w dyskusji na zajęciach z gerontologii społecznej, jak wyobrażają sobie własną starość, z reguły odpowiadają, że w ogóle sobie jej nie wyobrażają i o tym nie myślą. Inni natomiast odczuwają lęk przed zniedołężnieniem (chorobami, zwłaszcza otępiennymi), samotnością i biedą.

Powstaje zatem pytanie, na ile obraz starości i osób starych kształtowany jest przez doświadczenia własne lub rodzinne, w jakim stopniu oparty na mediach, a w jakim budowany na podstawie sztuki. O ile w podstawowych grupach społecznych obraz ten jest wynikiem własnej obserwacji, doświadczeń i obiegowych, płaskich przekazów, o tyle w grupach elitarnych wpływ na te postawy może mieć również sztuka, która posługując się uniwersalnym językiem przeżyć, potrafi oddać w sobie wszystkie treści nie gubiąc niczego z ich emocjonalnej wymowy. Dlatego też sztuka spełnia to wielkie zadanie cywilizacyjne przez mobilizowanie sumień, inspirowanie wyobraźni.

W wychowaniu estetycznym postuluje się włączanie do procesu kształtowania człowieka wielorakich wartości - wielorakich dzieł, a nie tylko tych, które wyrażają tradycyjnie pojęte klasyczne piękno. Takie nowoczesne ujęcie wychowawczego znaczenia sztuki pozwala z łatwością odpowiedzieć na pytanie, dlaczego może być piękny obraz przedstawiający brzydkiego, starego człowieka i na czym polega wychowawcze znaczenie takiego obrazu; nietrudno także zrozumieć, że sztuka zawierająca w sobie nieraz ogromny ładunek bólu, pełna dramatycznego napięcia i niepokoju wzbogaca wewnętrznie człowieka, który ją przeżywa i pomaga mu zrozumieć dramat ludzkiego życia. 
Sztuka w swoich formach i treściach szczególnie trudnych i złożonych powraca niejako do problemów życia, poszukuje ich sensu w pozornym bezsensie, ich wielkości w konfliktach i dramatach. Taka sztuka pokazuje człowieka, który w tym szczególnym uwikłaniu odnajduje prawdę o sobie.

\section{Polityka SPOŁECZna WOBeC PROBlemóW StAROŚCI}

W Polsce koncentruje się ona zwykle wokół potrzeb podstawowych i bezpieczeństwa socjalnego. Do najważniejszych jej zadań zalicza się:

- zapewnienie starości pozycji równoprawnej z innymi fazami;

- kształtowanie pozytywnego obrazu starości w świadomości społecznej;

- kształtowanie prawidłowych relacji międzypokoleniowych oraz promowanie działań wzmacniających więzi międzypokoleniowe;

- wzmocnienie aktywności osób w wieku poprodukcyjnym i wykorzystanie ich potencjału w środowisku lokalnym przez promowanie projektów służących integracji społecznej, wzmacnianie lokalnych wspólnot sąsiedzkich i wspieranie rozmaitych form samoorganizacji;

- zorganizowanie pomocy lub opieki domowej dla seniorów, aby mogli pozostać w swoim środowisku tak długo, jak to tylko możliwe;

- przygotowanie człowieka współczesnego do własnej starości (Szatur-Jaworska, Błędowski, Dzięgielewska, 2006, s. 291-292).

W państwach Unii Europejskiej mamy do czynienia z różnymi modelami opieki nad osobami starymi (Księżopolski, 2007, s. 143-161; Górecki, 2013, s. 301-313; Golinowska, 2018). W modelu anglosaskim, zwanym także liberalnym, marginalnym (Wielka Brytania, Irlandia) rola państwa jest bardzo ograniczona. Opiekuńcze funkcje państwa zostają sprowadzone do nauczenia ludzi, jak sobie radzić bez tego państwa. Toteż jego miejsce zastępować powinny sektory prywatny i pozarządowy, które w ten sposób uzyskują szerokie pole działania, następuje też odwoływanie się do zasady solidaryzmu, która zakłada, że pomoc powinna być przede wszystkim realizowana w układach wzajemnościowych.

W modelu konserwatywnym, zwanym również motywacyjnym, korporacyjnym lub kontynentalnym (Niemcy, Austria, Belgia, Francja, Luksem- 
burg), choć państwo nie bierze pomocy społecznej na swoje barki, to jednak jest ona prowadzona przez organizacje pozarządowe w wysokim stopniu zbiurokratyzowane i od niego uzależnione. Istotną rolę w nim odgrywają Kościoły i związki wyznaniowe, które zwykle przywiązują dużą wagę do zachowania tradycyjnych wartości rodzinnych. Wpływa to jednocześnie na zminimalizowanie znaczenia sektora prywatnego. Model ten został ukształtowany w wyniku zaawansowanego współdziałania państwa z sektorem pozarządowym. Dlatego tworzące je organizacje upodobniły się do instytucji publicznych. Są one z reguły dużymi instytucjami, zatrudniającymi personel etatowy i tylko w nieznacznym stopniu korzystające z wolontariuszy.

W modelu socjaldemokratycznym, zwanym też skandynawskim, instytucjonalnym (Szwecja, Dania, Finlandia) odpowiedzialność za dobrobyt i bezpieczeństwo socjalne obywateli ponosi państwo, które koncentruje się na potrzebach i dobru poszczególnych jednostek. Wytraca też swoje znaczenie kontrola społeczna, ponieważ dostęp do świadczeń i usług socjalnych jest najczęściej konkretnie określony prawem, warunki ich uzyskania zaś są zazwyczaj bardzo łatwe do spełnienia i odwołują się raczej do faktów niż ocen.

Model śródziemnomorski (południowoeuropejski) charakteryzuje się słabo rozwiniętym systemem polityki społecznej i jest właściwy dla południowych państw europejskich (Włochy, Hiszpania, Portugalia, Grecja). W krajach tych pomoc ze strony władz publicznych jest gwarantowana w bardzo wąskim zakresie. Obejmuje ona przede wszystkim osoby stare, którym zapewnia się wczesne i wysokie świadczenia emerytalne. Są one zdane na wsparcie ze strony Kościołów, które prowadzą rozwiniętą działalność charytatywną oraz rozmaite formy samopomocowe. W społeczeństwach tych główny ciężar pomocy spoczywa na rodzinach.

Model postkomunistyczny (kraje Europy Środkowej i Wschodniej) cechuje się niskim nakładem finansowym na opiekę zdrowotną oraz opiekę osobistą nad seniorami. Brak wystarczającej liczby instytucji państwowych, kierujących usługi opiekuńcze do osób starych wymagających tego typu działań, jest zazwyczaj zastępowany przez organizacje pozarządowe, w tym też religijne. Jednakże najważniejszą rolę w udzielaniu pomocy osobom starym odgrywa rodzina. 
Z doświadczeń Europy Zachodniej wynika, że państwa dobrobytu większą skuteczność odnoszą w polityce reaktywnej (przystosowanie infrastruktury do potrzeb osób starych) i w polityce aktywizacji (przygotowanie do aktywnej starości). Polska w tym zakresie nie wypada najlepiej. Zwraca się uwagę szczególnie na niski poziom aktywności ekonomicznej Polaków w wieku przedemerytalnym, niski średni wiek rzeczywistego przechodzenia na emeryturę i niski poziom aktywności społecznej seniorów. Dlatego postuluje się koncentrację działań wokół idei aktywnego starzenia się (active ageing), ale rozumianej nie tylko jako aktywizacja samych osób starych, lecz także jako przygotowanie instytucji publicznych, prywatnych i pozarządowych do aktywnej obecności seniorów w przestrzeni publicznej, na rynku pracy i w społeczeństwie obywatelskim.

Jednym z najpoważniejszym wyzwań jest zapewnienie opieki osobom niesamodzielnym (niezdolnych do samodzielnej egzystencji). Kwestia ta w polskiej polityce została zupełnie zmarginalizowana. W rezultacie Polska jest dzisiaj krajem praktycznie nieprzygotowanym i bezbronnym w starciu z efektami znacznie postępującego procesu starzenia się populacji, nie prowadzi się też spójnej i kompleksowej polityki demograficznej.

W Polsce i w wielu innych krajach europejskich opieka długoterminowa (long-term care - LTC) osób niesamodzielnych jest znacznie zdeinstytucjonalizowana i zapewniana przede wszystkim przez rodzinę i krewnych ${ }^{5)}$. Konieczne stają się systemowe rozwiązania na poziomie makro (polityka państwa) i mezo (polityki lokalne), a przede wszystkim na poziomie mikro - dotyczące małych grup, rodzin i pojedynczych osób, gdzie muszą nastąpić poważne zmiany aktualnie obowiązujących modeli opieki.

Opieka nad ludźmi starymi w Polsce jest świadczona w różnym zakresie przez rozmaite instytucje, działające w obrębie kilku obszarów. „Tradycyjnie wyróżnia się trzy podstawowe sektory: sektor opieki domowej (środowiskowej - domiciliary care; w Polsce to opieka środowiskowa, domowa oraz półotwarta), sektor instytucjonalnej opieki społecznej (którego celem jest niwe-

5) Z badań wynika, że około $80 \%$ osób w wieku 65 lat i więcej nie korzysta z żadnej opieki instytucjonalnej ani z opieki domowej świadczonej przez osoby trzecie (Bank Światowy, 2015, s. 15). 
lowanie zależności funkcjonalnej - residential care; w Polsce to domy pomocy społecznej, domy dziennej opieki, rodzinne domy pomocy) oraz sektor instytucjonalnej opieki medycznej (który jest wyraźnie zorientowany na medyczny wymiar opieki - hospital care; w Polsce to zakłady pielęgnacyjno-opiekuńcze oraz szpitale, szczególnie oddziały geriatryczne)" (Jackson, 1998; Jurek, 2007; za: Anacka, Janicka, Kaczmarczyk, 2014, s. 37-38).

W Polsce zdecydowanie dominującą formą jest opieka domowa, świadczona przez członków rodziny (szczególnie kobiety). Dlatego instytucje państwowe poniekąd „czują się zwolnione” z odpowiedzialności. Rodziny więc ponoszą główny ciężar opieki, nie mogąc liczyć na wsparcie. Jedną $\mathrm{z}$ istotnych konsekwencji stosowanych takich rozwiązań jest łączenie przez kobiety aktywności zawodowej z opieką nad dziećmi/wnukami i pokoleniem najstarszym lub wczesne rezygnowanie z pracy. Szczególnie ważną kwestią staje się więc odciążenie pokolenia „środkowego” (aktywnego ekonomicznie) pomocą na rzecz dzieci/wnuków i starzejących się rodziców.

Wzrost zapotrzebowania na usługi opiekuńcze sprawia, że niezbędne jest zwiększenie środków publicznych przeznaczonych na finansowanie tych usług i na świadczenia rzeczowe sprowadzające się do zaopatrzenia w niezbędne artykuły (np. materace, balkoniki, podnośniki, pionizatory, wózki umożliwiające kąpiel pod prysznicem itp.) oraz wprowadzenie istotnych zmian w regulacji prawnej. Wdrożenie koniecznych działań wymaga zarówno systemowego podejścia, jak i ścisłej współpracy administracji rządowej z administracją lokalną, gdyż potrzeby seniorów znacznie lepiej mogą zostać rozpoznane na poziomie regionalnym.

Istotne też staje się zapewnienie kompleksowej opieki geriatrycznej i hospicyjnej-paliatywnej (ponad 60\% pacjentów hospicyjnych-paliatywnych stanowią osoby powyżej 60 lat - Górecki, 2000, s. 111, 112), uelastycznienie zatrudnienia kobiet (dostępność pracy w niepełnym wymiarze i tymczasowej, jak również możliwość wyboru godzin pracy i dostosowanie ich do pozazawodowych obowiązków), zorganizowania niedrogiej opieki tymczasowej dla seniorów i opieki wytchnieniowej, czyli wsparcia dla opiekuna, gdy on sam zachoruje albo musi odpocząć, zwiększenie liczby domów opieki dziennej (placówki te odciążają opiekunów rodzinnych i jednocześnie umożliwiają ludziom starym pozostawanie w ich środowisku lokalnym), 
wzrost liczby osób świadczących usługi opiekuńcze (aktywizowanie do tej pracy bezrobotnych, w tym kobiet w wieku okołoemertylanym i emerytów; wprowadzenie ułatwień zatrudniania imigrantów; rozszerzenie sieci rodzinnych i angażowania dalszych krewnych, przyjaciół, sąsiadów, spontanicznych grup samopomocowych; wspieranie wolontariatu senioralnego, np. młodsi seniorzy, jako wolontariusze, mogliby się opiekować starszymi, niesformalizowanego wolontariatu - nieformalnej pomocy ludziom starym czy pomocy wzajemnościowej).

Podsumowując, należy podkreślić, że zachodzące procesy demograficzne wymuszają do przeorientowania zadań państwa, np. przyjmowanie nowych priorytetów w polityce społecznej i dokonywania zmian w sektorze finansów publicznych w celu zaspokajania potrzeb rosnącej liczby ludzi starych, a nie zastępowanie ich działaniami, które mają tylko na celu zaspokajanie potrzeb doraźnych i rozwiązywanie doraźnych problemów społecznych.

\section{AKTYWNOŚĆ EDUKACYJNA I SPOŁECZNA OSÓB STARYCH}

Idea aktywnego życia we wszystkich jego fazach, pomyślnego starzenia się oraz samodzielnej starości (nie dotyczy to rzecz jasna osób w pełni niesprawnych fizycznie i intelektualnie) jest upowszechniana z dwóch powodów: dla obalenia pejoratywnych skojarzeń na temat starości i związanych z nią stereotypów oraz dla nadania odpowiedniej rangi zasadzie ustawicznej partycypacji w życiu społecznym i wykorzystania potencjału seniorów dla dobra ogółu społeczeństwa. W tym miejscu trzeba też zwrócić uwagę na bardzo istotną kwestię: istotnym czynnikiem przeżywania starości i doświadczania jej skutków jest to, do jakiej grupy społecznej człowiek należy.

Do najbardziej popularnych w Polsce form samoorganizacji i społecznego zaangażowania osób starych należą szczególnie uniwersytety trzeciego wieku i kluby seniora. I choć ich działalność jest podobna, to w przypadku klubów seniora wyraźniejsza staje się idea samoorganizacji, a zwłaszcza na wsi lub małych miejscowościach. Wymienić można też i inne, a mianowicie takie jak domy dziennego pobytu, centra aktywności seniorów, grupy religijne, rozmaite koła o charakterze kulturalno-oświatowym, zespoły śpiewacze i taneczne. 
Istotnym pojęciem dla podejmowanej tu problematyki jest edukacja permanentna (kształcenie ustawiczne), która polega na stałym odnawianiu oraz doskonaleniu umiejętności i postaw, mogących przyczynić się do poprawy jakości życia i osiągnięcia satysfakcji życiowej, a także całożyciowym uczeniu się (Milerski, Śliwerski, 2000, s. 55).

Skuteczny sposób zapobiegania negatywnym efektom procesu starzenia się ludności stanowi przygotowanie się do starości, które rozumiane jest zazwyczaj jako zadanie dla jednostek i jako zadanie dla zbiorowości. W pierwszym przypadku oznacza to określone działania, które podejmuje dana osoba w celu poprawy swojej sytuacji życiowej po przekroczeniu progu starości, w drugim zaś - działania podejmowane przez podmioty państwowe, samorządowe, instytucje społeczne, nastawione na zaspokojenie w przyszłości potrzeb społeczeństwa, w którym wzrasta udział osób starych.

Istotnego znaczenia w owym przygotowaniu się do starości nabiera przygotowanie do emerytury, organizowane przez przedsiębiorstwa, związki zawodowe, samorządy lub uniwersytety trzeciego wieku. Treść tych spotkań jest następująca: emerytura - jej prawne i ekonomiczne ramy, zmiany dokonujące się w życiu po przejściu na emeryturę, sprawy materialne, zabezpieczenie się przed zubożeniem, profilaktyka i higiena zdrowotna, sposoby prawidłowego odżywiania, kultura fizyczna, zachowanie dobrego stanu zdrowia i samopoczucia, zorganizowanie i wykorzystanie czasu wolnego, poszukiwanie wartości i celu życia przez uczestnictwo w życiu społecznym.

„W krajach o powszechnym udziale w życiu umysłowym - pisała Radlińska (1938, s. 88) - starzenie się przychodzi coraz później. W związku z tym faktem zjawia się potrzeba spożytkowania sił najstarszych. Takiego, któreby przy zapewnionym bycie, w swobodnej pracy ochotniczej wnosiło wartości, właściwe temu okresowi życia”. W Polsce wolontariat senioralny jest wysoko cenioną aktywnością społeczną ludzi zaawansowanych wiekiem, którzy zakończyli swoje kariery zawodowe. Można wymienić trzy specyficzne funkcje tego typu wolontariatu. Pierwsza z nich polega na wykorzystaniu ich doświadczenia, umiejętności i kwalifikacji zawodowych w pracy rozmaitych organizacji pozarządowych lub zespołach wolontariackich. Po drugie, wolontariat seniorów jest szansą na zrealizowanie przezeń zaprzepaszczonych planów, niespożytkowanych talentów, zaniedbanych 
zainteresowań, które obowiązki rodzinne i zawodowe przesuwały w sferę niespełnionych aspiracji. Po trzecie, ludzie nie chcą być zepchnięci w samotną ciszę, pragną zachować sprawność fizyczną, umysłową i psychiczną, uczestniczyć w życiu społecznym i towarzyskim, bywa, że chcą też zostawić po sobie ślad w pamięci potomnych (Górecki, 2013, s. 168).

Przykładem aktywności seniorów jest łódzka inicjatywa „Latające babcie”, czyli starsze panie piszące i opowiadające bajki dzieciom w placówkach opiekuńczych, przedszkolach i szpitalach. Podobnym przedsięwzięciem może być „Wędrujący klub czytających dzieciom” w Warszawie. Innym ciekawym pomysłem jest realizowany także w stolicy przez Fundację na Rzecz Kobiet „Ja Kobieta” i Klub Kobiet Ravensbrück, zrzeszający byłe więźniarki obozu, projekt tworzenia grup seniorek o wspólnych doświadczeniach ${ }^{6}$.

Służbę wolontariacką seniorów organizują również organizacje międzynarodowe, które włączają je w projekty realizowane za granicą. Mają one charakter edukacyjny. Są nastawione na wymianę doświadczeń, umożliwienie kontaktów z cudzoziemcami, które uczą szacunku i rozumienia problemów ludzkich w kontekście międzykulturowym (np. program „Grundtvig” i program „Uczenie się przez całe życie”).

Uzupełnieniem wolontariatu seniorów jest wolontariat dla seniorów, zajmujący się organizacją wsparcia dla osób starych - chorych, niedołężnych, samotnych lub znajdujących się w trudnej sytuacji życiowej (np. stowarzyszenia „mali bracia Ubogich) (Górecki, 2013, s. 170).

\section{Podsumowanie}

Rozpatrując problem starzenia się i starości, można sformułować następujące zadania, które wynikają dla polityki społecznej i organizacji opieki geriatrycznej:

- integracja międzypokoleniowa, która daje szansę różnym grupom wiekowym przez obserwację i uczestnictwo na zrozumienie zmian zachodzących w życiu osób starych. Pogłębia ją wzajemne uczenie się

6) Informacje te, które są tylko ilustracją problemu zaczerpnięto ze stron internetowych wymienionych organizacji. 
przez dialog międzypokoleniowy nastawiony na obustronny przekaz wiedzy, tradycji i oglądu dawnego świata z jednej strony, a współczesnych procesów cywilizacyjnych i kulturowych z drugiej strony;

- świadome przygotowanie się do starości. Najczęściej rozumie się przez niepogodzenie się ze stopniowym zanikaniem sprawności fizycznej i spowolnieniem procesów umysłowych. Trzeba jednak zwrócić uwagę na to, że zmiany te - wyraźnie dostrzegane przez otoczenie - z trudem uzmysławiają sobie sami zainteresowani bądź to ze względu na zanikanie krytycyzmu, bądź przez mechanizm wypierania, polegający na niedopuszczaniu do świadomości myśli wywołujących niepokój i lęk. Są to rzecz jasna zabiegi symboliczne, oparte na samoobronnej interpretacji sytuacji, co nie zmienia jej obiektywnego obrazu. Siłę tego czynnika wzmaga dążenie do podtrzymywania poczucia własnej wartości, zwłaszcza gdy niektóre jej symptomy mają charakter upokarzający, a podejmowane zabiegi są odbierane jako przejaw lekceważenia woli. Z tą konstatacją wiąże się pomijany w literaturze problem poddania się trosce opiekuna. Stąd też ważnym elementem edukacji jest wytwarzanie w nastawieniu psychicznym osoby starzejącej się gotowości do ufnego poddania się przedsięwzięciom opiekuńczym. Brak takiej dyspozycji jest jedną z ważnych barier sprawnej i efektywnej pomocy;

- kształtowanie pozytywnych postaw wobec starości i seniorów poprzez organizowanie różnych zajęć w placówkach edukacyjnych i społeczne kampanie edukacyjne, a także postrzeganie populacji ludzi starych nie jako uciążliwy problem, lecz jako wyzwanie i szansę na pożyteczne współbycie (np. rozwój tzw. srebrnej gospodarki czy wolontariat senioralny). Warto zauważyć, że np. wzrost pozytywnych postaw studentów wobec starości następuje ze względu na uczestniczenie w zajęciach z gerontologii społecznej i geriatrii ${ }^{7)}$;

- włączanie osób starych w życie społeczne (np. zajęcia na uniwersytetach trzeciego wieku);

7) Badania przeprowadzone przez Zofię Szarotę na krakowskiej uczelni pedagogicznej (Szarota, 2004, s. 51-53), a także doświadczenia własne. 
- promowanie aktywnego i zdrowego stylu życia nie tylko wśród seniorów, lecz także wszystkich mieszkańców;

- organizowanie wsparcia społecznego i zabiegów pielęgnacyjno-opiekuńczych;

- upowszechnianie wiedzy (edukacji) gerontologicznej (rozumienie specyfiki, potrzeb, deficytów ludzi starych), czego koniecznym elementem powinno być również zorganizowanie placówek poradnictwa zwłaszcza dla osób, które nie są w stanie same rozwiązać trudnych sytuacji związanych z tego rodzaju opieką, kształcenie gerontologiczne i przygotowanie kadr do pracy z seniorami, a także uwrażliwienie jednostek i grup społecznych na tę tematykę.

Te zadania mogą być spełnione tylko w warunkach społecznego spokoju, porozumienia i silnych więzi społecznych, z równoczesnym brakiem konfliktu wobec aksjologicznych pryncypiów. Wszak zdaniem Radlińskiej zasadniczym celem wychowania jest poszukiwanie i wzmacnianie „sił i dążeń ludzkich", potencjałów zdolnych do budowy i przebudowy środowiska życia człowieka.

\section{BiblografiA}

Anacka, M., Janicka, A., Kaczmarczyk, P. (2014). Zmiany zasobów pracy i ich ekonomiczne konsekwencje oraz inne ekonomiczne konsekwencje starzenia się populacji. Studia i Materiaty, 4, Ośrodek Badań nad Migracjami. Warszawa: Uniwersytet Warszawski. http://migageing.uw.edu.pl/wp-content/uploads/ sites/36/2015/03/SiM_04.pdf, dostęp: 19.04.2019.

Bank Światowy (2015). Stan obecny i przyszłość opieki długoterminowej w starzejącej się Polsce. Uwagi na potrzeby opracowania polityki dotyczącej opieki długoterminowej. http://www.niesamodzielnym.pl/uploads/Bank\%20\%C5\%9Awiatowy\%20Opieka_dlugoterminowa.pdf, dostęp: 20.04.2019.

Butler, R.N. (1969). Age-ism: Another form of bigotry. The Gerontologist, 4, $243-$ 246.

Butler, R.N. (1975). Why survive? Being old in America. San Francisco: Harper \& Row.

Golinowska S. (2018). Modele polityki spotecznej w Polsce i Europie na poczatku XXI wieku. Warszawa: Fundacja im. Stefana Batorego. http://www.batory.org. $\mathrm{pl} /$ upload/files/Programy\%20operacyjne/Forum\%20Idei/Modele\%20polityki\%20spolecznej.pdf, dostęp: 24.09.2019. 
Górecki, M. (2000), Hospicjum w stużbie umierających. Warszawa: Wydawnictwo Akademickie Żak.

Górecki, M. (2013), Idea, instytucjonalizacja i funkcje wolontariatu. Warszawa: Wydawnictwo Akademickie „Żak”.

Harwas-Napierała, B., Trempała, J. (2003). Psychologia rozwoju cztowieka. Charakterystyka okresów życia cztowieka (t. 2). Warszawa: Wydawnictwo Naukowe PWN.

Izdebski, Z., Paprzycka, E. (2016). Single i singielki. Intymność i seksualność osób żyjacych w pojedynkę. Warszawa: Difin.

Jackon, W.A. (1998). The Political Economy of Population Ageing. Cheltenham: Edward Elgar.

Janiak-Jasińska, A., Sierakowska, K., Szwarc, A. (2016). Ludzie starzy i starość na ziemiach polskich od XVIII do XXI wieku (na tle porównawczym) (t. 1-2). Warszawa: Wydawnictwo DiG.

Jurek, Ł. (2007). Sektory opieki długoterminowej - analiza kosztów. Gerontologia Polska, 4, 111-115.

Kaczmarek, L., Skubalanka, T., Grabias, S. (1994). Stownik gwary studenckiej. Lublin: Wydawnictwo UMCS.

Kamiński, A. (1978). Studia i szkice pedagogiczne. Warszawa: PWN.

Księżopolski, M. (2007). Polityka społeczna w różnych krajach i modele polityki społecznej. W: G. Firlit-Fesnak, M. Szylko-Skoczny (red.), Polityka spoteczna. Podręcznik akademicki. Warszawa: WN PWN.

Kwak, A. (2005). Rodzina w dobie przemian. Matżeństwo i kohabitacja. Warszawa: Wydawnictwo Akademickie Żak.

Leiblum, S.R., Segraves, T.R. (2005). Terapia seksualna osób w podeszłym wieku. W: S.R. Leiblum, R.C. Rosen (red.), Terapia zaburzeń seksualnych. Tłum. D. Golec, A. Rozwadowska, J. West, E. Wojtych (s. 487-516). Gdańsk: GWP.

Milerski, B., Śliwerski, B. (2000). Pedagogika. Warszawa: WN PWN.

Marshall, G. (red.). (2004). Stownik socjologii i nauk spotecznych (red. nauk. pol. wyd. M. Tabin). Warszawa: WN PWN.

Nelson, T.D. (2005). Ageism. Prejudice against our feared future self. Journal of Social Issues, 2, 207-221. http://gatherthepeople.org/Downloads/Ageism_Prejudice.pdf, dostęp: 18.04.2019.

Okólski, M. (red.). (2018). Wyzwania starzejącego się spoteczeństwa. Polska dziś i jutro. Warszawa: Wydawnictwa UW.

Potent-Ambroziewicz, M. (2013). Starość w języku mtodzieży wspótczesnej. Lublin: Wydawnictwo UMCS.

Radlińska, H. (1938). O wartości życia ludzkiego (Odczyt wygłoszony w Polskim Radio). Życie Mtodych, 3-4, 84-89.

Rocznik Demograficzny (2019). Warszawa: Główny Urząd Statystyczny.

Storr, A. (2010). Samotność. Powrót do jaźni. Tłum. J. Prokopiuk, P.J. Sieradzan. Warszawa: Wydawnictwo W.A.B.

Szlendak, T. (2000). Rodzina. W: Encyklopedia socjologiczna (t. 3). Warszawa: Oficyna Naukowa. 
Szarota, Z. (2004). Gerontologia spoteczna i oświatowa. Zarys problematyki. Kraków: Wydawnictwo Naukowe Akademii Pedagogicznej.

Szukalski, P. (2008). Ageizm - dyskryminacja ze względu na wiek. W: J.T. Kowaleski, P. Szukalski (red.), Starzenie się ludności Polski - między demografia a gerontologia spoteczna (s. 153-184). Łódź: Wydawnictwo UŁ.

Szatur-Jaworska B., Błędowski P., Dzięgielewska M. (2006). Podstawy gerontologii spotecznej. Warszawa: Oficyna Wydawnicza ASPRA-JR.

World Population Aging (2013). New York: United Nations. http:/www.un.org/ en/development/desa/population/publications/pdf/ageing/WorldPopulation Ageing2013.pdf, dostęp: 17.04.2019.

\section{AGING AND OLD AGE IN THE ASPECT OF SOCIAL POLICY}

\section{ABSTRACT}

Recently, interest in the aging process of the Polish society and the phenomenon of old age has risen among social pedagogues, although though rarely they have been undertaken in research and publications in the field of this discipline. The article presents selected aspects and consequences of this issue and related social challenges. Focus has been placed on aging as a global demographic process, social attitudes towards elderly people and old age, different models of care for the elderly in European Union countries, educational and social activity of seniors. At the end, the most important tasks have been defined for social policy and organisation of geriatric care.

Keywords: aging, old age, attitudes, preparation for old age, social policy 